\title{
Catalytically Active Systems of Cobalt Complexes with Water-Soluble Phthalocyanines
}

\author{
Artur Vashurin,,${ }^{\mathrm{a}, @ @ ~}$ Ilya Kuzmin $_{1}{ }^{\mathrm{a}}$ Mikhail Razumov, ${ }^{\mathrm{a}}$ Oleg Golubchikov, ${ }^{\mathrm{b}}$ \\ and Oscar Koifman ${ }^{\mathrm{b}}$ \\ Dedicated to Professor Oleg Golubchikov on the occasion of his 70th Birthday \\ anorganic Chemistry Department, Ivanovo State University of Chemistry and Technology, 153000 Ivanovo, Russia \\ ${ }^{\mathrm{b}}$ Research Institute of Macroheterocycles, Ivanovo State University of Chemistry and Technology, 153000 Ivanovo, Russia \\ ${ }^{\mathrm{C}}$ Kazan Federal University, 420008 Kazan, Russia \\ ${ }^{\circledR}$ Corresponding authorE-mail: asvashurin@mail.ru
}

\begin{abstract}
The work reports catalytic properties of series of cobalt phthalocyanines peripherally substituted with consistently changing sulfonated fragments. Data on heterogenization of cobalt phthalocyaninates onto organic and inorganic polymers are provided. Comparing catalytic activity of the macrocycles in dependence on structure and peripheral substituent as well as polymer carrier's type is given. Application of cobalt phthalocyanine's sulfonic acids for fine synthesis of thiuram E upon both homogeneous and heterogeneous catalysis is shown to be prospective.
\end{abstract}

Keywords: Cobalt phthalocyaninate, sulfo-group, modification, catalyst, heterogenization, efficiency.

\section{Каталитические системы на основе комплексов кобальта с водорастворимыми фталоцианинами}

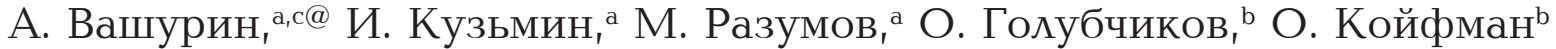 \\ Посвящается профессору Олегу Александровичу Голубчикову по случаю его 70-летия
}

\author{
а Кафедра неорганической химии, Ивановский государственный химико-технологический университет, 153000 \\ Иваново, Россия \\ ${ }^{\mathrm{b}}$ Институт химии макрогетерочииклов, Ивановский государственный химико-технологический университет, 153000 \\ Иваново, Россия \\ 'Казанский Федеральный Университет, 420008 Казань, Россия \\ @E-mail: asvashurin@mail.ru
}

\begin{abstract}
В работе приводится краткое обобщение каталитических свойств для ряда сульфированных производных фталочичанината кобальта, имеюших закономерно изменяющиеся по структуре периферические заместители. Приводятся сведения о гетерогенизации фталоцианинатов кобальта в органические и неорганические полимеры. Проводится сравнение каталитической активности макроциклов в зависимости от структуры их периферического заместителя и типа полимерного носителя. Показана перспектива применения сульфокислот фталоцианината кобальта в тонком органическом синтезе тиурама Е, как в гомогенном, так и гетерогенном катализе.
\end{abstract}

Ключевые слова: Фталоцианинат кобальта, сульфогруппа, модификация, катализатор, гетерогенизация, эффективность. 


\section{Introduction}

Fine tuning phthalocyanine nature by introducing bulky and elongated functional substituents into peripheral and non-peripheral positions as well as possibility of obtaining complexes with almost all metal based on them makes such compounds to be very applicable. Large amount of works concerning synthesis of phthalocyanines and its metal complexes ${ }^{[1-8]}$ prove chemical modification of phthalocyanine to be boundless including obtainment of dimeric, ${ }^{[9-12]}$ annulated, ${ }^{[13-16]}$ conjugated, ${ }^{[17-21]}$ and polymeric structures. ${ }^{[22-25]}$ Metallophthalocyanines are applied as stable pigments ${ }^{[26]}$ modern materials for photovoltaic cells, ${ }^{[27-28]} \mathrm{MOF},{ }^{[29-30]}$ optically active systems, ${ }^{[31-35]}$ sensitizers for PDT, ${ }^{[36]}$ prospective catalysts, and photocatalysts. ${ }^{[37-41]}$

Metal phthalocyaninates exhibit catalytic properties for various redox processes. ${ }^{[37]}$ In this way cobalt phthalocyaninates as Merox process' catalys ${ }^{[42]}$ allow performing liquid-phase oxidation of mercaptans (RSH) under mild conditions. Oxidation of RSH under harsh conditions proceeds according to Scheme 1 giving a quite big number of by-products.

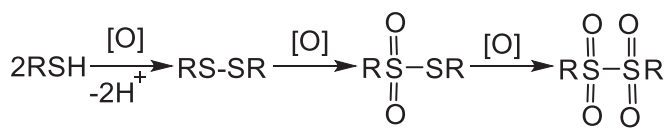

Scheme 1. Scheme of RSH oxidation.

Use of $d$-metal phthalocyaninates increases selectivity of the reaction depending on process' conditions. This fact opens up wide prospects for synthesis of practically-useful disulfides. ${ }^{[43-44]}$ Being among them so-called thiuramylsulfides, derivatives of dithiocarbamic acids are produced in tons. Application of air oxygen upon the process increases quality of desired product and provides meeting green chemistry principles. ${ }^{[45-47]}$

Maintaining efficiency of the catalyst is of great importance from manufacturing point of view. In order to reach this point one need fundamental data on mechanisms of catalytic action of metal phthalocyaninates upon redox processes of both homo- and heterogeneous kinds.

Present report is an overview of recent works performed by us and new data on catalytic activity of peripherally- sulfonated cobalt phthalocyaninates (Figure 1) upon homogeneous and heterogeneous catalysis of RSH oxidation.

\section{Experimental}

\section{Reactants}

Solvents used in the work were purified and stored in accordance with recommendations. ${ }^{[48]}$ Inorganic salts applied for synthesis were previously recrystallized by methods recommended in. ${ }^{[49]}$ Deuterated solvents, initial nitrophthalonitriles for phthalocyanines synthesis were purchased from Aldrich. Sodium $N, N$-diethylcarbamodithioate (DTC) (99\%, ChemMed Synthesis, Russia) was used without additional purification.

\section{Equipment}

Elemental analysis has been carried out by means of chromatographic analyzer Flash HCNS-OEA 1112 (Germany). The flow rates of helium and oxygen were $140 \mathrm{~mL} / \mathrm{min}$ and $250 \mathrm{~mL} /$ min, respectively; the temperature of the reactor was $1173 \mathrm{~K}$, oxygen was supplied into the reactor for $250 \mathrm{~mL} / \mathrm{min}$ with $12 \mathrm{sec}$ time delay.

FT-IR spectra were recorded using IR-Fourier spectrophotometer Avatar 360 (USA) in $400-4000 \mathrm{~cm}^{-1}$ frequency range.

NMR spectra of the solutions were recorded by means of NMR spectrometer Bruker AVANCE-500 (Germany) at operating frequency $500 \mathrm{MHz}\left({ }^{1} \mathrm{H}\right)$ and $100 \mathrm{MHz}\left({ }^{13} \mathrm{C}\right)$. Measurements were performed under the Fourier transformation conditions in 5 $\mathrm{mm}$ cells at various temperatures. Chemical shifts were measured with reference to the internal standard - tetramethylsilane. The accuracy of measurements was $\pm 0.005 \mathrm{ppm}$.

Electron absorption spectra (UV-Vis) were registered by means of Unico 2800 (USA) spectrophotometer in a spectral range of $200-1000 \mathrm{~nm}$. Quarts optical cell were used for the measurements. UV-Vis spectra were recorded at $298.15 \pm 0.03 \mathrm{~K}$.

Atomic force microscopy in a tapping mode was performed using an atomic force microscope Solver P47-PRO (NT-MDT, Russia) controlled from a PC using the "Nova" software package. Scanning step was $0.6 \mathrm{~nm}$. The powder of the hybrid material was fixed on the substrate through adhesion.

Mass spectra were measured on an Axima MALDI-TOF mass-spectrometer (Shimadzu, Japan).

\section{Macrocycles characterization}

Cobalt phthalocyanine tetrasulfonic acid (CoPcl) was synthesized by known Weber-Busch method. ${ }^{[50]}$ Obtained blue-green<smiles></smiles><smiles></smiles><smiles>[R]Oc1cc(S(=O)(=O)O)c2ccc(S(=O)(=O)O)c(S(=O)(=O)O)c2c1</smiles><smiles>[R]Oc1cc([As](=O)(=O)O)c2ccc(S(=O)(=O)O)cc2c1</smiles><smiles>[R]Oc1ccc(C(C)(C)c2ccc(S(=O)(=O)O)cc2)cc1</smiles>

Figure 1. Sulfonated derivatives of cobalt phthalocyaninates. 
precipitate was separated by filtrating, washed with ethanol-methanol mixture (3:1) and dried. Found, \%: C 37.82, H 1.79, N 11.18. $\mathrm{C}_{32} \mathrm{H}_{16} \mathrm{~N}_{8} \mathrm{O}_{12} \mathrm{~S}_{4}$ Co. Calculated, \%: C 39.51, H 1.87, N 11.53. IR spectra $(\mathrm{KBr}) \vee \mathrm{cm}^{-1}: 1720,1632,1502,1452,1489,1409,1379$, $1134,1049,935,770,618 .{ }^{1} \mathrm{H}$ NMR $(500 \mathrm{MHz}) \delta_{\mathrm{H}}$ ppm: $7.91(\mathrm{Ar}-$ H), 8.29 (Ar-H), 8.53 (Ar-H).

3,10,17,24-Tetrakis(6-sulfonaphthalen-2-yloxy)phthalocyaninate of cobalt (CoPc2) was synthesized according to. ${ }^{[51]}$ The product was additionally purified by chromatography on silica gel M 60 using aqueous DMF (1:1 by volume) as eluent. Yield $0.39 \mathrm{~g}(54 \%)$; blue-green powder, readily soluble in water, aqueous DMF, DMSO, and aqueous alkali. Found, \%: C 58.42, H 2.70, N 7.62, S 8.80. $\mathrm{C}_{72} \mathrm{H}_{40} \mathrm{CoN}_{8} \mathrm{O}_{16} \mathrm{~S}_{4}$. Calculated, \%: C 59.22, N 2.74, N 7.68, S 8.80. IR $v \mathrm{~cm}^{-1}: 1045$ ( $\mathrm{S}=\mathrm{O}$, sym.), 1103 ( $\mathrm{S}=\mathrm{O}$, asym.), $1205(\mathrm{C}-\mathrm{O}-\mathrm{C})$.

3,10,17,24-Tetrakis(6,8-disulfonaphthalen-2-yloxy)phthalocyaninate of cobalt ( $\mathrm{CoPc} 3$ ) was synthesized in a similar way to $^{[51]}$ from $1.01 \mathrm{~g}$ of dipotassium 7-(1,3-dioxo-2,3-dihydro- $1 \mathrm{H}$ isoindol-2-yloxy)naphthalene-1,3-disulfonate. Yield $0.53 \mathrm{~g}(59 \%)$; blue-green powder, readily soluble in water, aqueous DMF, DMSO, and aqueous alkali. Found, \%: C 48.32, H 2.20, N 6.23, S 14.43. $\mathrm{C}_{72} \mathrm{H}_{40} \mathrm{CoN}_{8} \mathrm{O}_{28} \mathrm{~S}_{8}$. Calculated, \%: C 48.57, H 2.25, N 6.30, S 14.39. IR $v \mathrm{~cm}^{-1}$ : 1039 ( $\mathrm{S}=\mathrm{O}$, sym.), 1103 ( $\mathrm{S}=\mathrm{O}$, asym.), 1210 (C-O-C).

Cobalt 2,9,16,23-tetrakis(1-benzotriazolyl)-3,10,17,24-tetrakis(4-sulfo-1-naphthoxy)phthalocyaninate (CoPc4) was synthesized according to ${ }^{[52]}$ by sulfonation initial phthalocyanine: 160 $\mathrm{mg}(0.1 \mathrm{mmol})$ of cobalt 2,9,16,23-tetrakis(1-benzotriazolyl)3,10,17,24-tetrakis(1-naphthoxy)phthalocyaninate was dissolved within $2 \mathrm{~mL}(18 \mathrm{mmol})$ of chlorosulfonic acid and $2 \mathrm{~mL}(18 \mathrm{mmol})$ of thionyl chloride mixture and stirred under $293 \mathrm{~K}$ for 2 hours. Further, reaction mixture was poured onto ice mixed with sodium chloride (0.1 mass fraction). Obtained precipitate was collected with Shotts' filter and dried in desiccators over concentrated $\mathrm{H}_{2} \mathrm{SO}_{4}$ for 72 hours. The sulfochlorides extraction was performed using acetone followed by drying. Next, hydrolysis of the sulfochlorides was carried out by boiling within distilled water. Final yield was $82-85 \%$. Additional purification was chromatography (sorbent - silica gel M 60, eluent - DMF). Elemental analysis found (\%): C 52.00, H 4.05, N, 12.43, S 5.36. $\mathrm{C}_{98} \mathrm{H}_{52} \mathrm{~N}_{20} \mathrm{~S}_{4} \mathrm{O}_{16} \mathrm{Co} \cdot 16 \mathrm{H}_{2} \mathrm{O}$. Calculated (\%): C 52.01, H 3.82, N 12.64, S 5.78. IR (KBr) $v \mathrm{~cm}^{-1}: 745$ (C-N), $1045(\mathrm{~N}=\mathrm{N}), 1230$ (Ar-O-Ar), 1060 (C-S), 1150-1190 (S=O в $\left.\mathrm{SO}_{3} \mathrm{H}\right) . \mathrm{m} / z$ (MALDI-TOF) $1932.71[\mathrm{M}+4 \mathrm{H}]^{+}$. NMR ${ }^{1} \mathrm{H}$ (DMSO$\left.-d_{6}\right) \delta_{\mathrm{H}} \mathrm{ppm}$ : $7.45(\mathrm{Ar}-5 \mathrm{H}), 7.94(\mathrm{Ar}-4 \mathrm{H}), 8.07(\mathrm{Ar}-6 \mathrm{H}), 8.29(\mathrm{Ar}-$ $3 \mathrm{H})$ - triazole group, $7.64(\mathrm{Ar}-8 \mathrm{H}), 7.73(\mathrm{Ar}-7 \mathrm{H}), 7.85(\mathrm{Ar}-11 \mathrm{H})$, 8.18 (Ar-10H), 8.53 (Ar-9H), 8.85 (Ar-12H) - naphthoxy group, $8.97\left(\mathrm{SO}_{3} \mathrm{H}\right)$.

Cobalt 2,9,16,23-tetrakis(1-benzotriazolyl)-3,10,17,24-tetrakis(1,6-disulfo-2-naphthoxy)phthalocyaninate(CoPc5) wassynthesized similarly to CoPc4. Cobalt 2,9,16,23-tetrakis(1-benzotriazolyl)-3,10,17,24-tetrakis(2-naphthoxy)-phthalocyaninate was used as initial macrocycle for sulfonating its substituents. Elemental analysis found (\%): C 42.29, H 4.42, N 9.73, S 9.36. $\mathrm{C}_{96} \mathrm{H}_{52} \mathrm{~N}_{20} \mathrm{~S}_{8} \mathrm{O}_{28} \mathrm{Co} \cdot 32 \mathrm{H}_{2} \mathrm{O}$. Calculated (\%): C 42.29, H 4.14, N 9.91, $\mathrm{S}$, 9.08. IR (KBr) $v \mathrm{~cm}^{-1}$ : $741(\mathrm{C}-\mathrm{N}), 1049(\mathrm{~N}=\mathrm{N}), 1262(\mathrm{Ar}-\mathrm{O}-\mathrm{Ar})$, 1091 (C-S), $1158\left(\mathrm{~S}=\mathrm{O}\right.$ in $\left.\mathrm{SO}_{3} \mathrm{H}\right) . \mathrm{m} / z$ (MALDI-TOF) $2248.82[\mathrm{M}]^{+}$. NMR ${ }^{1} \mathrm{H}\left(\mathrm{DMSO}-d_{\sigma}\right) \delta_{\mathrm{H}}$ ppm: 7.48 (Ar-5H), 7.75 (Ar-4H), 7.94 (Ar$-6,7 \mathrm{H}), 8.14(\mathrm{Ar}-3 \mathrm{H})$ - triazole group, $8.33(\mathrm{Ar}-2 \mathrm{H})$ - macrocycle, $8.72(\mathrm{Ar}-8,9,11 \mathrm{H})$ - naphthoxy group, 8.83, $8.81\left(\mathrm{SO}_{3} \mathrm{H}\right)$.

Cobalt tetra-4-[(1,6-disulfonaphthyl)-2-oxy]-tetra-5-nitrophthalocyaninate ( $\mathrm{CoP} \mathrm{C} 6$ ) was synthesized by direct sulfonation initial phthalocyanine obtained from corresponding phthalodinitrile according to. ${ }^{[33]}$ Cobalt tetra-4-(2-naphthoxy)-tetra-5-nitrophthalocyaninate $(132 \mathrm{mg}, 0.1 \mathrm{mmol})$ and $2 \mathrm{~mL}(18 \mathrm{mmol})$ of chlorosulfonic acid and $2 \mathrm{~mL}$ ( $18 \mathrm{mmol})$ of thionyl chloride were loaded into doble-necked flask equipped with stirrer and refluxed. The solution was stirred under $20^{\circ} \mathrm{C}$ for 2 hours. Next, the mixture was poured onto ice treated with sodium chloride. Formed precipitate was collcted with Shotts' filter and dried in disiccator over sulfuric acid for 3 days. Desired compounds were extracted using acetone, solvent was removed and $10 \mathrm{~mL}$ of water was added, after it was heated up until complete dissolving. Final step is liquid column chromatography on silica gel M60 using DMF as eluent. Solvent in final was removed. Yield: $167.2 \mathrm{mg}$ (85\%). Found, \%: C 40.78, N 11.96, H 2.63, S 11.88, O 33.59. $\mathrm{C}_{72} \mathrm{H}_{52} \mathrm{CoN}_{12} \mathrm{O}_{44} \mathrm{~S}_{8}$. Calculated, \%: C 41.09, N 7.99, H 2.49, S 12.19, O 33.45. m/z (MALDITOF) $[\mathrm{M}+2 \mathrm{Na}+2 \mathrm{H}]^{+}=2008.22$, calculated: 1960.55 , (2104.67 for hydrated molecule). Sum of obtained data suggests presence of eight water molecules being part of macrocycle $\mathrm{C}_{72} \mathrm{H}_{36} \mathrm{CoN}_{12} \mathrm{O}_{36} \mathrm{~S}_{8} \cdot 8 \mathrm{H}_{2} \mathrm{O}$.

Tetra-4-\{4-[1-methyl-1-(4-sulfophenyl)ethyl]phenoxy\}tetra5-nitrophthalocyaninate of cobalt ( $\mathrm{CoPc} 7)$ was synthesized by method. ${ }^{[54]}$ Tetra-5-[4-(1-methyl-1-phenylethyl)phenoxy]tetra4-nitrophthalocyaninate of cobalt $(160 \mathrm{mg}, 0.01 \mathrm{mmol})$ was combined with mixture of $2 \mathrm{~mL}(18 \mathrm{mmol})$ of chlorsulfonic acid and $2 \mathrm{~mL}(18 \mathrm{mmol})$ of thionyl chloride under room temperature for 2 hours. The reaction mixture was poured onto ice treated with sodium chloride after the stirring is finished. Formed precipitate was collected by means of Shotts filter, dried in exicator over sulfuric acid for 3 days. Obtained sulfochloride was extracted with acetone, the solvent was distilled off. The mixture next was boiled with water till entire dissolving. The solvent then was distilled off. Final purification was performed by column chromatography: eluent - DMF, sorbent - silica gel M 60. Obtained products are solid compounds of dark-green color soluble in water, ammonia solution water-alkali solutions, DMF. Yield is $137 \mathrm{mg}$ (72\%). Found, \%: C 57.71, N 8.56, H 3.96, S 6.38. $\mathrm{C}_{92} \mathrm{H}_{68} \mathrm{CoN}_{12} \mathrm{O}_{24} \mathrm{~S}_{4}$. Calculated, \%: C 57.77, N 8.79, H 3.58, S 6.70. IR (KBr) v cm-1 2919,2852 $\left(\mathrm{CH}_{3}\right), 1504$ (as $\left.\mathrm{NO}_{2}\right), 1340$ (as $\left.\mathrm{NO}_{2}\right), 1174$ (S=O), 1020 (C-S).

\section{Results and Discussion}

\section{Liquid-phase oxidation of sodium}

$N, N$-carbamodithiolate in presence of homogeneous phthalocyanine catalysts

The most promising medium for performing liquidphase processes in view of green chemistry is undoubtedly water. Sulfonic acid fragments being part of phthalocyanine macrocycle impart solubility in water and water-alkali media within broad range of concentrations, that is positive in terms of catalytic application. However, the problem of selfassociating macrocycle molecules within a solution appears. Propensity of metallophthalocyaninates to form dimeric, trimeric and other associates within water and water-alkali mediums is known. ${ }^{[5]]}$ The works ${ }^{[51-54]}$ found out phthalocyaninates presented in Figure 1 to aggregate differently. The aggregation begins upon quite low concentrations of the macrocycle $\sim 10^{-6} \mathrm{~mol} / \mathrm{L}$.

Stability of dimeric associates and tetrasubstituted phthalocyaninates increases according to the following $\mathrm{CoPc} 3<\mathrm{CoPc} 2<\mathrm{CoPc}^{[51]}$ correlating with electronic effects of peripheral substituents being proof of effect of total substituent's nature, not just presence of certain functional groups. Introducing additional functional substituent into the fifth position leads to changes in influence of periphery's structure and geometry on physicochemical properties of entire macrocycle. When effects of substituents in fourth and fifth positions of annulated benzene fragment are equal one has to expect joint action of the substituents and increasing certain properties of the macrocycle. If the effects are opposite then competing action takes place. This is applicable for fine tuning physico-chemical properties of tetrapyrrolic macroheterocycles. 
Expanding the series by bifunctionally-substituted cobalt phthalocyaninates indicates enhancing peripheral fragment's electronic influence on the macrocycle to affect aggregational state of the phthalocyanine. In this case stability of dimeric associates in water decreases as following $\mathrm{CoPc} 5>>\mathrm{CoPc} 6>\mathrm{CoPc} 1>\mathrm{CoPc} 2>\mathrm{CoPc} 4>\mathrm{CoPc} 3$. The series reflects effect of peripheral substituent's nature on association. The position of CoPc5 is of certain interest. Stability of the associates is the highest despite eight ionized sulfo-groups being part of the macrocycle. This corresponds to inhibition of electrostatic repulsion of conformationallymobile peripheral substituents by compensating deficiency of electronic density upon interaction between the macrocycles being part of associate. Disturbing aromatic conjugation of benzene fragments on the periphery ( $\mathrm{CoPc} 7)$ does not lead to significant change in aggregation state of the macrocycle. In addition, presence of strong electron-accepting group increases intensity of dimerization for almost two times compared to tetrasubstituted macrocycles. ${ }^{[54]}$ All these facts are considered upon analyzing catalytic activity of studied cobalt phthalocyanines.

Cobalt tetrasulfophthalocyaninate $(\mathrm{CoPc} 1)$ is to be acknowledged as starting point upon investigating interrelationship between substituent's structure and physicochemical properties of a phthalocyanine. All four sulfo-groups have maximal effect being part of CoPc1. We previously found the macrocycle's structure and its coordination ability to play the key role for catalytic process. ${ }^{[56-58]}$ DTC oxidation takes place in kinetic region upon constant oxygen and catalyst concentration as well as solution's $\mathrm{p} H$. We approved earlier non-catalytic oxidation of DTC to be almost non-existent $\left(k_{\text {obs }}=1.7 \cdot 10^{-5} \mathrm{~s}^{-1}\right) \cdot{ }^{[59]}$ Non-linearity of $k_{\text {obs }}$ dependence from concentration for $\mathrm{CoPcl}$ with tendency to become plane upon high concentration of the macrocycle is caused by selfassociation of the catalyst described above. Table 1 contains parameters of DTC oxidation in presence of homogeneous catalysts $\mathrm{CoPc} 1-\mathrm{CoPc} 7$.

Table 1. Parameters of liquid-phase oxidation of DTC $\left(c_{\text {DTC }} 2.7 \cdot 10^{-3}\right.$ $\mathrm{M}$ ) in water-alkali solution ( $\mathrm{pH}$ 9.4) in presence of homogeneous phthalocyanine catalysts $\left(c_{\mathrm{CoPc}} 4.7 \cdot 10^{-5} \mathrm{M}\right)$ under $298.15 \mathrm{~K}$.

\begin{tabular}{cccc}
\hline catalyst & $-\lg k_{\mathrm{obs}}$ & $\chi_{\text {RSSR }}, \%$ & $-\lg k_{\mathrm{diss}}$ \\
\hline CoPc1 & 4.1 & 82 & 3.93 \\
CoPc2 & 4.28 & 80 & 3.81 \\
CoPc3 & 3.9 & 79 & 3.65 \\
CoPc4 & 4.01 & 73 & 3.72 \\
CoPc5 & 4.14 & 84 & 4.36 \\
CoPc6 & 4.08 & 82 & 3.88 \\
CoPc7 & 4.28 & 86 & 6.74 \\
\hline
\end{tabular}

The most appropriate concentration range for homogeneous catalysis taking into account association behavior of metallophthalocyanines $\mathrm{CoPc} 1-\mathrm{CoPc} 7$ was found to be from $4 \cdot 10^{-6}$ to $6 \cdot 10^{-5} \mathrm{~mol} / \mathrm{L}$, upon which the effect of association factor is linear. Distribution of catalytic activity of studied macrocycles upon DTC oxidation in this concentration range is unchanged and corresponds to $\mathrm{CoPc} 3>\mathrm{CoPc} 4>\mathrm{CoPc} 6>\mathrm{CoPc} 1 \geq \mathrm{CoPc} 5>\mathrm{CoPc} 2 \geq \mathrm{CoPc} 7$. The series is out of full correlation with dimeric associates in solutions (Figure 2) that doubts statement concerning strict decrease of catalytic activity upon association of metallophthalocyanines in solution.

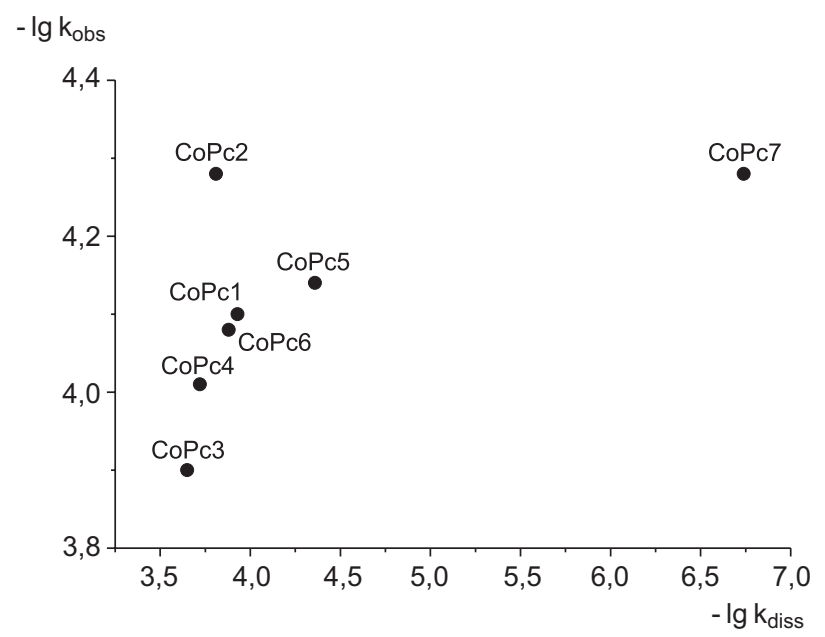

Figure 2. Dependence of CoPc association state on its catalytic activity upon homogeneous catalytic DTC oxidation.

Exponential nature of association dependence on catalytic properties of $\mathrm{CoPc} 1-\mathrm{CoPc} 7$ suggests existence of additional factor affecting catalytic activity of cobalt phthalocyaninates.

Disulfide dissociates in water-alkali media according to equation (1):

$$
\mathrm{RSH}+\mathrm{NaOH} \leftrightarrows \mathrm{RS}^{-}+\mathrm{Na}^{+}+\mathrm{H}_{2} \mathrm{O}
$$

where RSH - DTC.

According to the equation (1) the substrate enters catalytic cycle as an ion, that is of certain importance. Ability of cobalt cation as a part of phthalocyanine macrocycle to additionally coordinate both molecular and charged ligands into fifth and sixth coordination positions leads to rivalry among solvent and substrate that in turn affects association state of entire system. ${ }^{[60-61]}$ Detailed analysis of coordination properties of studied phthalocyaninates is presented in. ${ }^{[58]}$ It is worth mentioning only that there is dependence between stability of molecular complexes CoPc1-CoPc7 of 1:1 composition having various ligands and its catalytic properties upon $\mathrm{RSH}$-substrates oxidation observed. Hence, one can conclude catalytic activity of metallophthalocyanines upon liquid-phase oxidation of DTC to be directly depended on both coordination center state, therefore type and stability of the associate in solution, and keeping coordination efficiency. This statement is in good agreement with known for now oxidation processes which, even though different, include one or several steps being coordination of a substrate and/or oxidizer on central metal cation. ${ }^{[62]}$

The mechanism of RSH-substrates oxidation involving phthalocyanine catalysts was proposed based on comprehensive kinetic studies of large number of water-soluble cobalt phthalocyaninates. The limiting step is formation of RS radicals according to the reaction 
$\mathrm{RS} \cdot \mathrm{Co}^{\mathrm{II}} \mathrm{Pc} \cdot \mathrm{O}_{2}^{-}+\mathrm{H}_{2} \mathrm{O} \rightarrow \mathrm{RS} \cdot+\mathrm{H}_{2} \mathrm{O} \cdot \mathrm{Co}^{\mathrm{III}} \mathrm{Pc} \cdot \mathrm{O}_{2}^{2-}$

The mechanism is represented by equations (2)-(6):

$\mathrm{RS}^{-}+\left(\mathrm{Co}^{\mathrm{II}} \mathrm{Pc}\right)_{2} \stackrel{\mathrm{K}_{1}}{\rightleftarrows} \mathrm{RS}^{\bullet} \cdot \mathrm{Co}^{\mathrm{I}} \mathrm{Pc}+\mathrm{Co}^{\mathrm{I}} \mathrm{Pc}$

$\mathrm{RS}^{\bullet} \cdot \mathrm{Co} \mathrm{Pc}+\mathrm{O}_{2} \stackrel{\mathrm{K}_{2}}{\rightleftarrows} \mathrm{RS}^{\bullet} \cdot \mathrm{Co}^{\mathrm{II}} \mathrm{Pc} \cdot \mathrm{O}_{2}^{-}$

$\mathrm{RS}^{\bullet} \cdot \mathrm{Co}^{\text {II Pc}} \cdot \mathrm{O}_{2}^{-}+\mathrm{H}_{2} \mathrm{O} \stackrel{\mathrm{k}_{3} \text {, slowly }}{\longrightarrow} \mathrm{RS} \cdot+\mathrm{H}_{2} \mathrm{O} \cdot \mathrm{Co}^{\text {III }} \mathrm{Pc}^{\circ} \cdot \mathrm{O}_{2}^{2-}$

$2 \mathrm{H}_{2} \mathrm{O} \cdot \mathrm{Co}^{\mathrm{III}} \mathrm{Pc} \cdot \mathrm{O}_{2}^{2-} \stackrel{\mathrm{k}_{4}}{\longrightarrow} 2 \mathrm{Co}^{\mathrm{II}} \mathrm{Pc}+\mathrm{H}_{2} \mathrm{O}_{2}+2 \mathrm{OH}^{-}$

$\mathrm{RS} \stackrel{\text { instantaneous }}{\longrightarrow} \mathrm{RSSR}$

It was established that increase of electron acceptor ability of spacer bridge in the substituent on periphery of phthalocyanine leads to increase in catalytic activity. ${ }^{[63-64]}$ Based on this mechanism the influence of the peripheral substituent nature on catalytic activity of the macrocycle is definitely depends on heteroatom effects affecting metal cation of phthalocyanine molecule, which in turn determines the stability of triple complex and aggregation degree of macrocycles in solution. Kinetic equation obtained using Michaelis-Menten formal kinetic describes these systems well and it is linearized in Lineweaver-Burke coordinates giving the equation (7).

$$
r=\frac{k_{3} \mathrm{~K}_{1} \mathrm{~K}_{2} c_{(\mathrm{CoPc})_{2}}^{\circ} c_{\mathrm{O}_{2}}^{\circ}}{1+\mathrm{K}_{1} c_{\mathrm{RS}^{-}}} \cdot c_{\mathrm{RS}^{-}}
$$

\section{Catalytic properties of cobalt phthalocyaninate sulfonic acids heterogenized in silicon dioxide}

Applying cobalt phthalocyaninates as catalysts for DTC oxidation one may decrease basicity of the medium to 8-9 $\mathrm{p} H$ values as well as use molecular oxygen as oxidizer ${ }^{[65]}$ that forms mild enough conditions and allows the reaction to proceed obtaining disulfide as a main product according to first step in Scheme 1. However, there is significant drawback of phthalocyaninate used as homogeneous catalysts being low manufacturability, ${ }^{[66]}$ especially upon extracting the catalyst out of reaction mixture and further activation.
One may control aggregation processes and thus catalytic activity of metallophthalocyanines by covalent and non-covalent immobilization onto solid-phase carriers. ${ }^{[67-71]}$ Such methods allow not only obtaining associates of desired sort but remove association ${ }^{[72]}$ and autocatalytic oxidation of tetrapyrrolic macroheterocycles absolutely. ${ }^{[73]}$ Adsorption from solutions and chemical anchoring of macrocycles onto surface of solid-phase carrier provide maximal dispersing. Tetrapyrrolic macroheterocycles like phthalocyanines are able to interact with active sites of solidphase carriers by various ways. ${ }^{[74-75]}$ All the interactions are to be realized by monomolecular layer contacting surface of solid-phase material only. In order to reach full immobilization anchor groups in the end of substituents of peripheral and non-peripheral positions of the macrocycle are generally used. ${ }^{[76-81]}$ The immobilization is usually performed through hydroxyl group (-OH), carboxyl group (-COOH), sulfo-group $\left(-\mathrm{SO}_{3} \mathrm{H}\right)$, and amine group $\left(-\mathrm{NH}_{2}\right)$. Porous materials of highly-developed surface having anchored phthalocyanine catalysts obtained by sol-gel method are the most promising from catalysis' point of view. ${ }^{[82]}$

Joint hydrolysis of $d$-metal phthalocyaninate's sulfonic acids and precursor for polymer matrix is carried out under consequent adding basic catalyst of polycondensation (triethylamine) that increases duration of the process and dispersion degree of a metallophthalocyanine within a polymer. General scheme of the process is presented in Figure 3.

The nature of immobilized phthalocyanine affects size of particles formed itself and character of its distribution significantly (Figure 4). ${ }^{[83-85]}$ Immobilized molecules of a phthalocyanine are also able to act upon hybrid particles formation as templates being structuring agents. The narrowest distribution of particle's size and the smallest particles were achieved for $\mathrm{SiO}_{2} @ \mathrm{CoPc} 2$ (Figure 4). Bigger number of substituents increases size of particles formed. For $\mathrm{SiO}_{2} @ \mathrm{CoPc} 3$ two closely located sulfo-groups contributes formation of rigid structural grid significantly. Introducing phthalocyanines into preliminary obtained matrix during adsorption is to be noticed to cause high degree of hybrid material's aggregation. ${ }^{[84]}$

Synthesized materials were found by laser diffraction of corresponding water suspensions to contain aggregated particles of less than $100 \mu \mathrm{m}$ size. Such aggregates were destroyed by ultrasonic treatment before the catalytic exper-

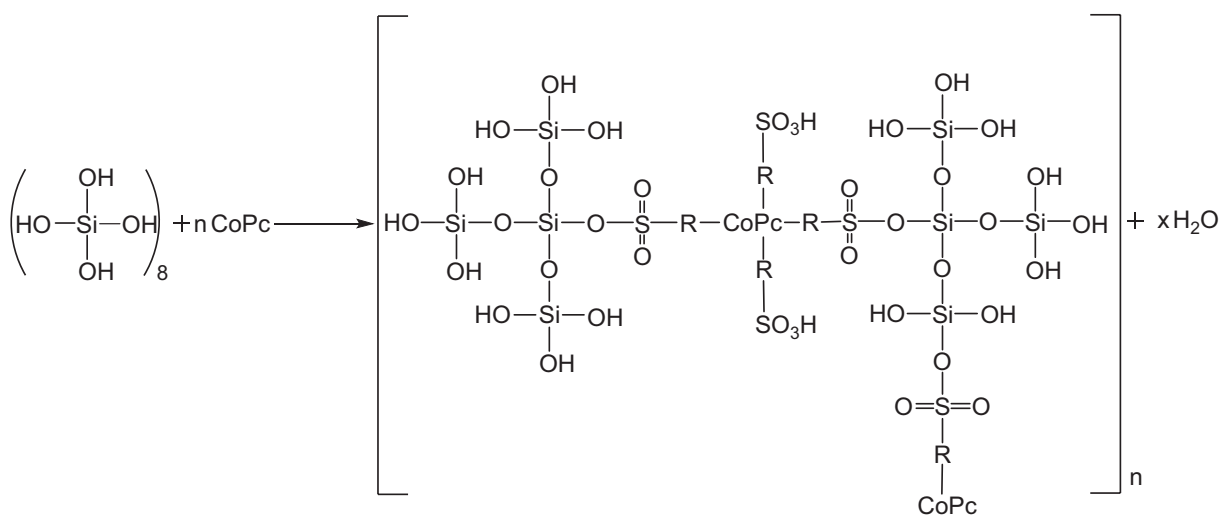

Figure 3. Joint polycondensation of CoPc and ortho-silicic acid. 


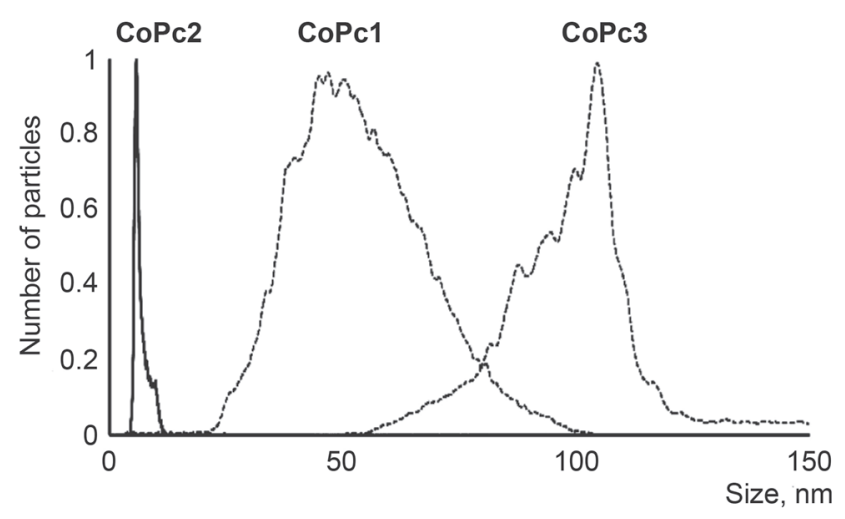

Figure 4. Particle size distribution of synthesized hybrid materials.

iment. Increasing amount and size of peripheral substituents of phthalocyanine molecule enlarges aggregated particles proving previous hypothesis about immobilized compound acting as template.

DTC oxidation was observed to slow down upon decreasing substrate's concentration lower than $70 \%$ under stationary conditions in presence of $\mathrm{SiO}_{2} @ \mathrm{CoPc}$ catalyst. This fact is caused by precipitating oxidation products, thiuram $\mathrm{E}$ in first, and blocking catalyst's pores. There are several ways to solve such complex task as maintaining activity of porous catalysts on a high level upon deactivation being pores blocked by substrates and reaction products. Ultrasonic treatment and mechanical remove of thiuram E from reaction mixture were used in current work in order to solve the task. This approach allowed performing the reaction using one portion of the catalyst for more than 10 cycles.

Observed efficiency of the catalyst obtained through adsorption of CoPcl by silicon dioxide matrix was overestimated compared to expected one. The macrocycle is washing out from catalyst's pores upon oxidation of DTC in water-alkali medium $(\mathrm{pH} \mathrm{8-13)}$ and its catalytical action is due to both homogenized and heterogenized forms. Additionally, the substrate is getting stuck within vacated pores, size of which is 2.5 time higher than those of material obtained by joint hydrolysis of the macrocycle and the precursor $\left(\mathrm{SiO}_{2} @ \mathrm{CoPc1}\right)$, by weak physical adsorption. In this way, the total efficiency is sum of several factors. According to spectral studies about (3.62-5.31) $10^{-7}$ of CoPcl is desorbing from pores of the catalyst obtained by phthalocyanine adsorbed by formed matrix.

Based on mechanism of heterogeneous oxidation of mercatptanes and thiols discussed in works ${ }^{[86-89]}$ and on similarity of homogeneous and heterogeneous ways of the catalysis one may conclude the set of elementary steps has to be equal for both catalyst's types. General mechanism includes nucleophilic coordination of a substrate by central cation of metallophthalocyanine followed by bonding of oxygen as second ligand forming paramagnetic supercomplex. The highest density of spin is known to be located on coordinated superoxide-ion. ${ }^{\left[{ }^{[0]}\right.}$ In this case transfer of two electrons from thiolate ion onto oxygen leads to forming disulfide radical and superperoxide ion. ${ }^{[91-93]}$ Thereby, increasing distance between a macrocycle and a silicon dioxide matrix has to decrease universal and weak coor- dination $\left(\mathrm{Co}^{\delta+} \ldots \mathrm{OH}^{\delta-}\right)$ interactions between pore's surface and phthalocyanine catalyst and increase free space for ligand. The last fact is valuable because Co-phthalocyanines are unlikely to additionally coordinate ligands by one side of the macrocycle. ${ }^{[94]}$

$$
\begin{aligned}
& \mathrm{RS}^{\cdot} \cdot \mathrm{Co}^{\mathrm{II}} \mathrm{Pc} \cdot \mathrm{O}_{2}^{-} \stackrel{\text { slow }}{\rightleftarrows} \mathrm{RS} \cdot+\mathrm{Co}^{\mathrm{III}} \mathrm{Pc}^{2} \cdot \mathrm{O}_{2}^{-} \rightarrow \\
& \rightarrow \mathrm{Co}^{\mathrm{III}} \mathrm{Pc} \cdot \mathrm{O}_{2}^{-} \stackrel{\mathrm{H}_{2} \mathrm{O}}{\rightleftarrows} \mathrm{Co}^{\mathrm{II}} \mathrm{Pc}+\mathrm{OH}^{-}+\mathrm{H}_{2} \mathrm{O}_{2}
\end{aligned}
$$

The highest catalytic efficiency among all studied systems is observed under temperature of $308.15 \mathrm{~K}$, that is most likely due to shift of substrate's ionization equilibrium (1) toward formation of $\mathrm{RS}^{-}$anions. Further increasing temperature leads to increasing activity of hydroxide-ions in solution which in turn enhances rivalry between $\mathrm{OH}^{-}$ and $\mathrm{RS}^{-}$ions for active cites, namely for being coordinated by central cation of phthalocyanine molecule. Analysis of resulting data allows to put the hybrid materials including tetraderivative of cobalt phthalocyaninate's sulfonic acids in series of catalytic activity fair for temperature range from 298.15 to $313.15 \mathrm{~K}: \mathrm{SiO}_{2} @ \mathrm{CoPc} 2>\mathrm{SiO}_{2} @ \mathrm{CoPc} 1>\mathrm{SiO}_{2} @$ $\mathrm{CoPc} 3$. The regularity suggests CoPc3 anchored on silica's surface by four covalent interactions to overcome greatest steric and electronic obstacles toward coordination of oxygen molecule and substrate.

Expansion of peripheral substituents' functionality in phthalocyanine macrocycle (CoPc4-CoPc7) changes morphology ${ }^{[95]}$ and simultaneously catalytic properties of obtained materials significantly. Additional substituent of both symmetrical nature toward the substituent located in fourth position of annulated benzene fragment and different from it introduced in fifth position changes distribution of electronic density within macrocycle ring. ${ }^{[96]}$ Using this factor, one can fine tunes physicochemical parameters of metal phthalocyaninates including catalytic activity by varying nature of such substituents. That phenomenon is also may be applied for obtainment of hybrid materials having, for example, one substituents being anchor for linking a matrix and another one affecting properties of the molecule itself.

Kinetic parameters' values of DTC oxidation in presence of heterogeneous catalysts containing bifunctionallysubstituted cobalt phthalocyaninates (Table 2) indicates the process to be caused mainly by diffusion of substrate within catalyst's pores.

The best conversion degree (95\%) was exhibited by the sample $\mathrm{SiO}_{2} @$ CoPc6 maintaining high oxidation rate. Nowadays heterogeneous catalysts based on CoPc1 anchored on hydrotalcites are known to reach maximal efficiency of $96 \%$ after 5 hours from reaction's start ${ }^{[97-98]}$ that is comparable to results of $\mathrm{SiO}_{2} @ \mathrm{CoPc} 6$ being much more easily recoverable.

\section{Catalytic properties of cobalt phthalocyaninate's sulfonic acids heterogenized in nonwoven polymer materials}

Hybrid materials based on metal phthalocyaninates and inorganic matrixes have high operational characteristics, 
Table 2. Kinetic parameters' values of DTC oxidation in presence of materials containing bifunctionally-substituted cobalt phthalocyaninates.

\begin{tabular}{ccccc}
\hline Catalyst & $-\lg k_{w}$ & $\begin{array}{c}E^{\neq}, \mathrm{kJ} / \\
\mathrm{mol}\end{array}$ & $\begin{array}{c}-\Delta S^{\ddagger}, \\
\mathrm{J} /(\mathrm{mol} \cdot \mathrm{K})\end{array}$ & $\chi_{\text {RSSR }} \%$ \\
\hline $\mathrm{SiO}_{2} @ \mathrm{CoPc} 1$ & 1.21 & 11.29 & - & 72 \\
$\mathrm{SiO}_{2} @ \mathrm{CoPc} 2$ & 0.95 & 63.39 & - & 84 \\
$\mathrm{SiO}_{2} @ \mathrm{CoPc} 3$ & 1.55 & 40.24 & - & 81 \\
$\mathrm{SiO}_{2} @ \mathrm{CoPc} 4$ & 0.83 & 26.11 & 202 & 80 \\
$\mathrm{SiO}_{2} @ \mathrm{CoPc} 5$ & 1.03 & 13.31 & 253 & 90 \\
$\mathrm{SiO}_{2} @ \mathrm{CoPc} 6$ & 0.87 & 26.77 & 202 & 95 \\
$\mathrm{SiO}_{2} @ \mathrm{CoPc} 7$ & 1.07 & 19.87 & 263 & 85 \\
\hline
\end{tabular}

namely high mechanical, chemical and thermal stability, making them engaging for industry. Despite all this there is significant drawback caused by high porosity being pores plugged by substrate, solvent and reaction products that poisons the catalyst. As a result, active sites of the catalyst are closed and the efficiency decreases. One way to solve this problem and hence increase the efficiency of catalyst is immobilization of metal phthalocyaninates onto surface of organic polymers of carbon nanotubes. ${ }^{[99-101]}$ Key role upon copolymerization and immobilization on a surface is taken by anchor group's formation. In this way, functional group being part of phthalocyanine able easily to form radical or ion becomes mandatory for successful immobilization. Sulfo-groups are among the best variants from that point of view. In order to covalently bind something with inert polymers one need to form reactive groups on the surface.

Even though chemical activation of the polymer allows efficient controlling set of formed functional groups within its structure upon catalyst's obtainment, ${ }^{[102]}$ the method is not appropriate enough from technological point of view. Plasma treatment is one of prospective ways of polymer's modification. ${ }^{\text {[103-104] }}$ Plasmochemical treatment of polymers can be divided conditionally into two types: "dry" is treatment by low-temperature gaseous

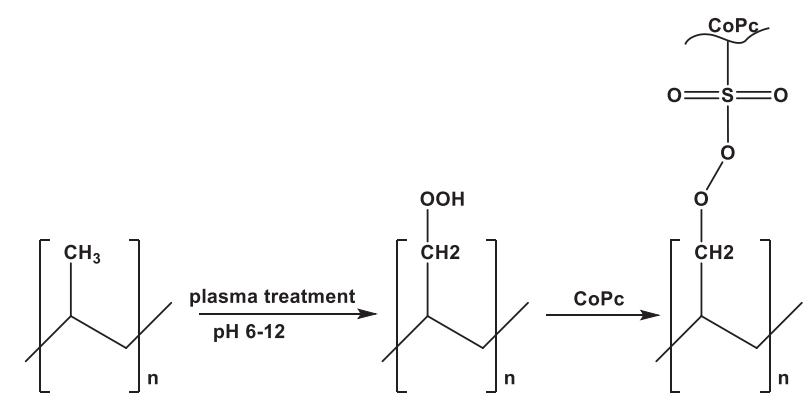

Scheme 2. Scheme of chain radical oxidation of polypropylene and immobilization of cobalt phthalocyaninate's sulfonic acids.

plasma and "wet" is treatment by plasma in solution systems. Interaction of plasma with polymer is complex multistep process proceeding various directions. Meanwhile, polymer treatment under such conditions proceeds within a layer of micrometers deep. There are vibrations of primary alcohol groups observed in IR spectrum at 1250 and $1035 \mathrm{~cm}^{-1}$ after treating nonwoven polymer in plasmachemical cell. Valent vibrations of $-\mathrm{OH}$ group in range of $3400 \mathrm{~cm}^{-1}$ is increasing upon accumulation. Besides, vibration band at $1565 \mathrm{~cm}^{-1}$ responsible for carboxylate-ion is registered. These facts indicate activation of the surface. The way of macrocycle's immobilization (Scheme 2) is suggested based on chain radical oxidation of polymer surface occurred upon activation by plasma.

Figure 5 represents local regions of aggregation after immobilization on polymer surface. Affinity degree of macrocycle toward polymer surface in such regions is obviously higher due to removing outer layers of aggregate during washing.

Hybrid materials having immobilized phthalocyaninates are not inferior to pure polymers in term of thermal stability. Figure 6 presents sample of destruction thermogram for a hybrid material.

Temperature of decomposing start for hybrid materials is lower for 10-20 degrees than for pure polymer, that obviously reflects beginning decomposition of polymermacrocycle bond within the material.
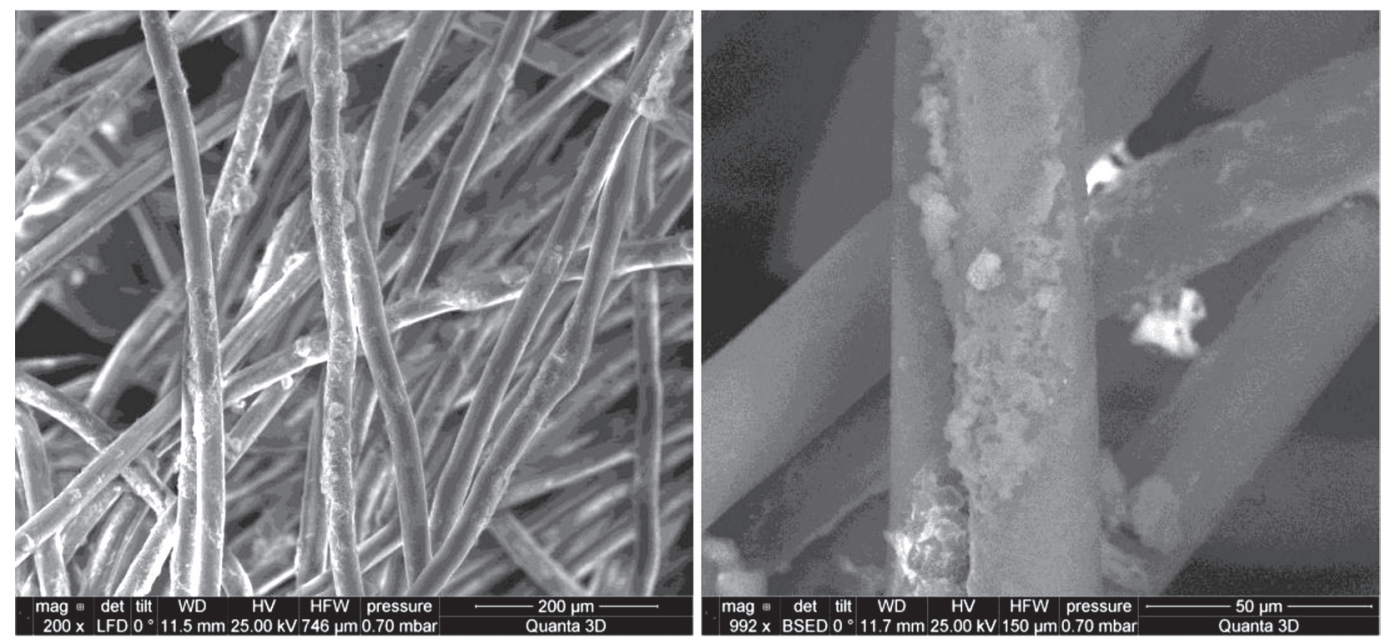

Figure 5. SEM images of polymer sample having immobilized CoPc2. Treatment by glow discharge for 15 minutes. 


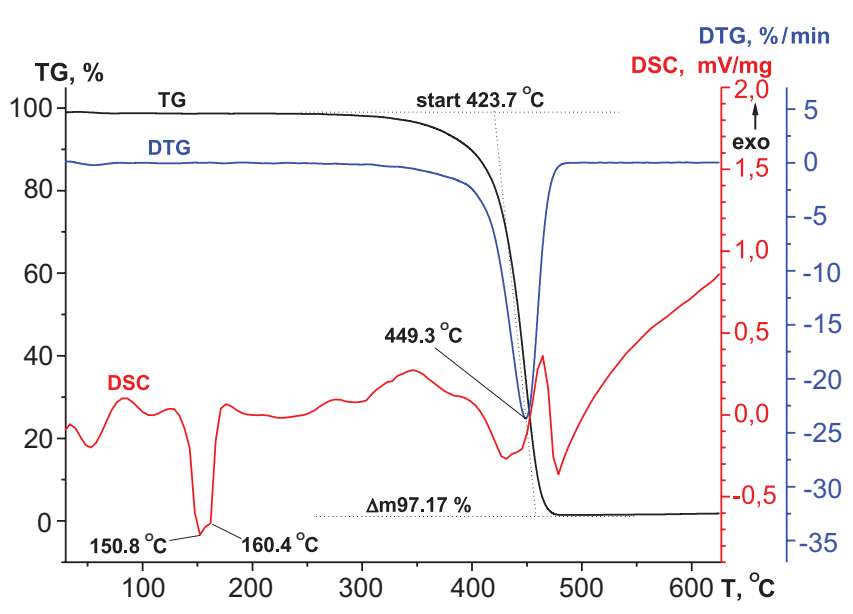

Figure 6. Destruction thermogram for polypropylene@CoPc3.

Similar phenomenon was observed in case of Lavsane. Comparison of oxidation efficiency using various catalysts (Table 3) indicates CoPc1 to exhibit close efficiency regardless to nature of polymer-carrier. When number of sulfo-groups contained in extended peripheral substituent is increased the catalytic activity is inversed upon immobilization on Lavsane compared to polypropylene, that is probably caused by changes of bonding type between macrocycle and polymer surface. ${ }^{[105]} \mathrm{CoPc} 1$ and $\mathrm{CoPc} 2$ predominantly forms equal bonds that differs from $\mathrm{CoPc} 3$ able to bond due to joint hydrolysis of two sulfo-fragments being part of one peripheral substituent that increase macrocycle fraction on polymer surface and hence increase the activity. In general, one can conclude catalytic activity of tetrasulfoderivatives of cobalt phthalocyaninate not to be affected by type of organic polymer. Presence of additional binding sites in case of octasubstituted derivatives enhances the activity due to increasing surface concentration of cobalt phthalocyaninate. And factor of non-covalent macrocycle-matrix becomes predominant.

Table 3. Effective rate constants of DTC oxidation in presence of polymer@CoPc heterogeneous catalysts.

\begin{tabular}{ccc}
\hline Phthalocyanine & \multicolumn{3}{c}{$-\lg k_{\mathrm{obs}}$} \\
& PP & Lavsan \\
\hline CoPc1 & 2.67 & 2.68 \\
CoPc2 & 2.39 & 2.49 \\
CoPc3 & 2.55 & 2.38 \\
\hline
\end{tabular}

\section{Conclusions}

Summarizing all above, cobalt phthalocyaninate's sulfonic acids are to be noticed as effective catalysts for selective producing thiuram $\mathrm{E}$ by oxidation of sodium $\mathrm{N}, \mathrm{N}$-carbamodithiolate under mild conditions. Catalytic activity of these compounds upon homogeneous catalysis of DTC oxidation is following $\mathrm{CoPc} 3>\mathrm{CoPc} 4>\mathrm{CoPc} 6>\mathrm{CoPc} 1 \geq \mathrm{CoPc} 5>\mathrm{CoPc} 2 \geq \mathrm{CoPc} 7$ and corresponds to the electronic and geometrical effects of peripheral substituents affecting macrocyclic core. On the basis of DTC oxidations mechanism these effects are to influence the state of central metal cation of the macrocycle significantly. Obviously, this is the reason for absence of dependence between H-dimers' stability and catalytic activity of CoPc. Though the last one correlates with stability of molecular complexes in water mediums. Bifunctionally-substituted phthalocyaninates being most aggregated upon homogeneous catalysis becomes the most efficient upon heterogeneous one when the compounds are immobilized in polymer matrixes due to leveling aggregational factor and solvate environment. Choose of a polymer depends on the process' features. Inorganic matrix of silicon dioxide is preferable in order to increase selectivity of a process. Nonwoven polymers are the most technological materials in terms of DTC oxidation in water mediums due to easiness of their removal from reaction mixture and further activation.

Acknowledgements. We are grateful to workers of Fine Organic Synthesis Department of ISUCT for kindly provided cobalt phthalocyaninates. The work was supported by grant of President of Russia for young PhD's (MK-161.2017.3).

\section{References}

1. Kadish K., Guilard R., Smith K. Phthalocyanines: Synthesis. In: The Porphyrin Handbook, Vol.15, Academic Press, 2002. $369 \mathrm{p}$.

2. Lukyanets E.A., Nemykin V.N. J. Porphyrins Phthalocyanines 2010, 14, 1-40.

3. Tuncer S., Kaya K., Özçeşmeci İ., Burat A. J. Organomet. Chem. 2017, 827, 78-85.

4. Çakır V., Göksel M., Durmuş M., Biyiklioglu Z. Dyes Pigm. 2016, 125, 414-425.

5. Bekaroğlu Ö. J. Porphyrins Phthalocyanines 2000, 4, 465-473.

6. Furuyama T., Satoh K., Kushiya T., Kobayashi N. J. Am. Chem. Soc. 2014, 136, 765-776.

7. Hanack M., Iqbal Z., Lyubimtsev A., Özcesmeci I., Özcesmeci M., Ziegler T. J. Porphyrins Phthalocyanines 2009, 13, 312-321.

8. Kulinich V., Shaposhnikov G., Badaukaite R. Macroheterocycles 2010, 3, 23-29.

9. Ali H., Lier J. Tetrahedron Lett. 2014, 55, 4163-4167.

10. Toriumi N., Muranaka A., Hashizume D., Uchiyama M. Tetrahedron Lett. 2017, 58, 2267-2271.

11. Karaoğlan G., Gümrükçü G., Gördük S., Can N., Gül A. Synth. Met. 2017, 230, 7-11.

12. Martynov A., Zubareva O., Gorbunova Y., Sakharov S., Tsivadze A. Inorg. Chim. Acta 2009, 362, 11-18.

13. Ikeue T., Sonoda M., Kurahashi S., Tachibana H., Teraoka D., Sugimori T., Kasuga K., Handa M. Inorg. Chem. Commun. 2010, 13, 1170-1172.

14. Ikeue T., Sawada N., Matsumoto N., Miyazaki A., Sugimori T., Koikawa M., Hiromitsu I., Yoshino K., Mikuriya M., Kataoka Y., Handa M. J. Porphyrins Phthalocyanines 2014, 18, 708-714.

15. Quartarolo A., Pérusse D., Dumoulin F., Russo N., Sicilia E. J. Porphyrins Phthalocyanines 2017, 17, 980-988.

16. Makarov S., Suvorova O., Wöhrle D. J. Porphyrins Phthalocyanines 2011, 15, 791-808.

17. Ali H., Baillargeon P., Lier J. Tetrahedron Lett. 2008, 49, 7253-7255.

18. Bizet F., Ipuy M., Bernhard Y., Lioret V., Winckler P., Goze C., Perrier-Cornet J., Decréau R. Bioorg. Med. Chem. 2018, 26 , $413-420$. 
19. Yanık H., Göksel M., Yeşilot S., Durmuş M. Tetrahedron Lett. 2016, 57, 2922-2926.

20. Li K., Qiu L., Liu Q., Lv G., Zhao X., Wang S., Lin J. J. Photochem. Photobiol., B 2017, 174, 243-250.

21. Birin K., Chugunov V., Krapivenko A., Gorbunova Y., Tsivadze A. Macroheterocycles 2014, 7, 153-161.

22. Geis C., Schneider S., Schlettwein D. J. Porphyrins Phthalocyanines 2016, 20, 1166-1172.

23. Sawada K., Duan W., Sekitani K., Satoh K. J. Mol. Liq. 2005, 119, 171-176.

24. Bilgin A., Yağc1 Ç. Eur. Polymer J. 2014, 61, 240-252.

25. Torre G., Torres T. J. Porphyrins Phthalocyanines 2002, 6, 274-284.

26. Chakraborty J. Fundamentals and Practices in Colouration of Textiles. WPI Publishing, 2014. p. 169.

27. Dao Q., Hori T., Fukumura K., Masuda T., Kamikado T., Fujii A., Shimizu Y., Ozaki M. Org. Electron. 2013, 14, 2628-2634.

28. Huang H., Cao Z., Li X., Zhang L., Liu X., Zhao H., Tan S. Synth. Met. 2012, 162, 2316-2321.

29. Wang K., Qi D., Li Y., Wang T., Liu H., Jiang J. Coord. Chem. Rev. 2017, doi: 10.1016/j.ccr.2017.08.023.

30. Zvyagina A., Shiryaev A., Baranchikov A., Chernyshev V., Enakieva Y., Raitman O., Ezhov A., Meshkov I., Grishanov D., Ivanova O., Gorbunova Y., Arslanova V., Kalinina M. New J. Chem. 2017, 41, 948-957.

31. Kobayashi N. Coord. Chem. Rev. 2001, 219-221, 99-123.

32. Safonova E., Martynov A., Nefedov S., Kirakosyan G., Gorbunova Y., Tsivadze A. Inorg. Chem. 2016, 55, 2450-2459.

33. Oluwole D., Yagodin A., Mkhize N., Sekhosana K., Martynov A., Gorbunova Y., Tsivadze A., Nyokong T. Chem. Eur. J. 2017, 23, 2820-2830.

34. Li Z., Gao F., Xiao Z., Wu X., Zuo J., Song Y. Optics Laser Technol. 2018, 103, 42-47.

35. Zhao P., Wang Z., Chen J., Zhou Y., Zhang F. Opt. Mater. 2017, 66, 98-105.

36. Tamura R., Kawata T., Hattori Y., Kobayashi N., Kimura M. Macromol. 2017, 50, 7978-7983.

37. Sorokin A. Chem. Rev. 2013, 113, 8152-8191.

38. Zhou W., Zhou J., Chen Y., Cui A., Sun F., He M., Xu Z., Chen Q. Appl. Catal., A 2017, 542, 191-200.

39. Gao Y., Chen L., Quan M., Zhang G., Zheng Y., Zhao J. J. Electroanal. Chem. 2018, 808, 8-13.

40. Luo R., Lin X., Lu J., Zhou X., Ji H. Chin. J. Catal. 2017, 38, 1382-1389.

41. Chauhan D., Kumar P., Painuly R., Kumar S., Jain S., Ganguly S. Fuel Process. Technol. 2017, 162, 135-146.

42. Bricker J., Laricchia L. Top. Catal. 2012, 55, 1315-1323.

43. Nemykin V., Polshyna A., Borisenkova S., Strelko V. J. Mol. Catal. A: Chem. 2007, 264, 103-109.

44. Goifman A., Guna J., Gitisa V., Kamyshny A., Leva J. Appl. Catal., B 2004, 54, 225-235.

45. Hassanein M., Gerges S., Abdo M., El-Khalafy S. J. Mol. Catal. A: Chem. 2005, 240, 22-26.

46. Ochoa G., Gutierrez C., Ponce I., Paez M., Pavez J., Zagal J., Silva J.F. J. Electroanal. Chem. 2010, 639, 88-94.

47. Kimura M., Yamaguchi Y., Koyama T. J. Porphyrins Phthalocyanines 1997, 1, 309-313.

48. Weissberger A., Proskauer E., Riddick J., Toops E. Organic Solvent: Physical Properties and Methods of Purification. New York: Publishers Inc., 1955. 447 p.

49. Karyakin Yu., Angelov I. Pure Chemicals Reagents. Moscow: Khimiya, 1974. 408 p. (in Russ.) [Карякин Ю.В., Ангелов И.И. Чистые химические вещества, М.: Химия, 1974. 408 с.].

50. Weber J., Busch D. Inorg. Chem. 1965, 4, 472-475.

51. Voronina A., Kuzmin I., Vashurin A., Shaposhnikov G., Pukhovskaya S., Golubchikov O. Russ. J. Gen. Chem. 2014, 84, 1777-1781.
52. Vashurin A., Filippova A., Znoyko S., Voronina A., Lefedova O., Kuzmin I., Maizlish V. J. Porphyrins Phthalocyanines 2015, 19, 983-996.

53. Vashurin A., Kuzmin I., Razumov M., Pukhovskaya S., Golubchikov O., Voronina A., Shaposhnikov G., Koifman O. J. Porphyrins Phthalocyanines 2015, 19, 1-9.

54. Filippova A., Vashurin A., Znoyko S., Kuzmin I., Razumov M., Chernova A., Shaposhnikov G., Koifman O. J. Mol. Struct. 2017, 1149, 17-26.

55. Snow A. Phthalocyanines: Properties and Materials. In: The Porphyrin Handbook, Vol. 17, Academic Press, 2003. p. 129-176.

56. Vashurin A., Kuzmin I., Litova N., Petrov O., Pukhovskaya S., Golubchikov O. Russ. J. Phys. Chem. 2014, 88, 2064-2067.

57. Vashurin A., Maizlish V., Kuzmin I., Petrov O., Razumov M., Pukhovskaya S., Golubchikov O., Koifman O. J. Incl. Phenom. Macrocycl. Chem. 2016, 87, 37-43.

58. Vashurin A. Russ. Chem. Bull. 2016, 65, 2220-2228.

59. Vashurin A., Pukhovskaya S., Semeikin A., Golubchikov O. Macroheterocycles 2012, 5, 72-75.

60. Chandra B.K.C., D'Souza F. Coord. Chem. Rev. 2016, 322, 104-141.

61. Vashurin A., Voronina-Chernova A., Maizlish V., Koifman O. Mendeleev Commun. 2017, 27, 16-18.

62. Tyapochkin E., Kozliak E. J. Mol. Catal. 2005, 242, 1-17.

63. Vashurin A., Maizlish V., Pukhovskaya S., Voronina A., Kuzmin I., Futerman A., Golubchikov O., Koifman O. J. Porphyrins Phthalocyanines 2015, 19, 573-581.

64. Vashurin A., Kuzmin I., Mayzlish V., Razumov M., Golubchikov O., Koifman O. J. Serb. Chem. Soc. 2016, 81, 1025-1036.

65. Kaliya O.L., Lukyanets E.A., Vorozhtsov G.N. J. Porphyrins Phthalocyanines 1999, 3, 592-610.

66. Anisimov A.V., Mohammed R.A., Borisenkova S.A., Tarakanova A.V., Barkanova S.V., Derkacheva V.M., Negrimovskii V.M., Kaliya O.L., Lukyanets E.A. Petrol. Chem. 1994, 34, 347-352.

67. Costa A., Ghesti G., de Macedo J., Braga V., Santos M., Dias J., Dias S. J. Mol. Catal. 2008, 282, 149-157.

68. Altın İ., Sökmen M., Bıyıklığlu Z. Mater. Sci. Semicond. Process. 2016, 45, 36-44.

69. Li P., Ding Y., Wang A., Zhou L., Wei S., Zhou Y., Tang Y., Chen Y., Cai C., Lu T. ACS Appl. Mater. Interfaces 2013, 5 , 2255-2260.

70. Bazarnik M., Brede J., Decker R., Wiesendanger R. ACS Nano 2013, 7, 11341-11349.

71. Gol'dshleger N., Baulin V., Tsivadze A. Prot. Metals Phys. Chem. Surf. 2014, 50, 135-172.

72. Hongbing Zh., Wenzhe Ch., Jianchun Ch., Minquan W. Mater. Sci. Eng., B 2003, 100, 119-123.

73. Hongbing Zh., Wenzhe Ch., Minquan W. Mater. Lett. 2003, 57, $1108-1112$.

74. Kuznetsova N., Kaliya O. Macroheterocycles 2015, 8, 8-19.

75. Morandeira A., López-Duarte I., Martínez-Díaz M., O'Regan B., Shuttle C., Haji-Zainulabidin N., Torres T., Palomares E., Durrant J. J. Am. Chem. Soc. 2007, 129, 9250-9251.

76. Fashina A., Antunes E., Nyokong T. Polyhedron 2013, 53, 278-285.

77. Zuev K., Perevalov V., Vinokurov E., Zhigunov F., Koldaeva T. Macroheterocycles 2016, 9, 250-256.

78. Ezhov A., Zhdanova K., Bragina N., Mironov A. Macroheterocycles 2016, 9, 337-352.

79. Makhseed S., Al-Kharafi F., Samuel J., Ateya B. Catal. Commun. 2009, 10, 1284-1287.

80. Akopyants Y.G., Borisenkova S.A. J. Mol. Catal. 1993, 83, $1-16$.

81. Synak A., Gil M., Organero J., Sánchez F., Iglesias M., Douhal A. J. Phys. Chem. C 2009, 113, 19199-19207. 
82. Zhao Z., Fan J., Wang Z. J. Cleaner Product. 2007, 15, 1894-1897.

83. Marfin Y., Vashurin A., Rumyantsev E., Puhovskaya S. J. Sol-Gel Sci. Technol. 2013, 66, 306-311.

84. Voronina A., Tarasyuk I., Marfin Y., Vashurin A., Rumyantsev E., Pukhovskaya S. J. Non-Cryst. Solids 2014, 406, 5-10.

85. Tarasyuk I., Kuzmin I., Marfin Y., Vashurin A., Voronina A., Rumyantsev E. Synth. Met. 2016, 217, 189-196.

86. Fisher H., Schulz-Ekloff G., Wöhrle D. Chem. Eng. Technol. 1997, 20, 624-632.

87. Hoffmann M., Hong A. Sci. Total Environ. 1987, 64, 99-115.

88. Borisenkova S. Petrol. Chem. 1991, 31, 391-408.

89. Schutten J., Beelen T. J. Mol. Catal. 1981, 10, 85.

90. Wohrle D., Buck T., Schneider G., Schulz-Ekloff G., Fischer H. J. Inorg. Organomet. Polym. 1991, 1, 115-130.

91. van Welzen J., van Herk A., German A. Macromol. Chem. Phys. 1987, 188, 1923.

92. Surdhar P., Armstrong D. J. Phys. Chem. 1986, 90, 5915.

93. Surdhar P., Armstrong D. J. Phys. Chem. 1987, 91, 6532.

94. Berezin B., Koifman O. Russ. Chem. Rev. 1980, 49, 2389-2417.
95. Vashurin A., Marfin Yu., Kuzmin I., Znoyko S., Rumyantsev E. J. Sol-Gel Sci. Technol. 2018, in press.

96. Makino M., Aihara J. J. Phys. Chem. A. 2012, 116, 8074-8084.

97. Chatti I., Chorbel A., Grange P., Colin J. Catal. Today 2002, 75, 113-117.

98. Liu H., Min E. Green Chem. 2006, 8, 6572.

99. Rayati S., Chegini E. Macroheterocycles 2016, 9, 151-155.

100. Rashidi A., Mirzaeian M., Khodabakhshi S. J. Nat. Gas Sci. Eng. 2015, 25, 103-109.

101. Vashurin A., Kuzmin I., Titov V., Pukhovskaya S., Razumov M., Golubchikov O., Koifman O. Macroheterocycles 2015, 8, 351-357.

102. Joseph J., Jain S., Sain B. Ind. Eng. Chem. Res. 2010, 49, 6674-6677.

103. Felix T., Trigueiro J., Bundaleski N., Teodoro O.M.N.D., Sério S., Debachera N. Appl. Surf. Sci. 2018, 428, 730-738.

104. Zaitsev A., Lacoste A., Poncin-Epaillard F., Bès A., Debarnot D. Surf. Coat. Technol. 2017, 330, 196-203.

105. Vashurin A.S., Badaukaite R.A., Futerman N.A., Pukhovskaya S.G., Shaposhnikov G.P., Golubchikov O.A. Petrol. Chem. 2013, 53, 197-200. 